\title{
Full-fat insect meals as feed additive - the effect on broiler chicken growth performance and gastrointestinal tract microbiota
}

\author{
A. Józefiak ${ }^{1,6}$, B. Kierończyk², M. Rawski ${ }^{2,3}$, J. Mazurkiewicz ${ }^{3,4}$, A. Benzertiha ${ }^{4}$, P. Gobbi ${ }^{4}$, \\ S. Nogales-Mérida ${ }^{4}$, S. Świątkiewicz ${ }^{5}$ and D. Józefiak ${ }^{2}$ \\ Poznań University of Life Sciences, \\ 1 Department of Preclinical Sciences and Infectious Diseases, Wołyńska 35, 60-637 Poznań, Poland \\ ${ }^{2}$ Department of Animal Nutrition, Wołyńska 33, 60-637 Poznań, Poland \\ ${ }^{3}$ Institute of Zoology, Division of Inland Fisheries and Aquaculture, Wojska Polskiego 71c, 60-625 Poznań, Poland \\ ${ }^{4}$ HiProMine S. A., Poznańska 8, 62-023 Robakowo, Poland \\ ${ }^{5}$ National Research Institute of Animal Production, Department of Nutrition Physiology, Krakowska 1, 32-083 Balice, Poland
}

KEY WORDS: microbiota, performance, poultry, insect protein

Received: 24 May 2017

Revised: 30 March 2018

Accepted: 11 June 2018

${ }^{6}$ Corresponding author:

e-mail: agata.jozefiak@up.poznan.pl

\begin{abstract}
The aim of this study was to evaluate the effect of full-fat insect meals fed 'on top' to broiler chickens on their performance and the microbiota composition in the gastrointestinal tract. A total of 1850 day-old Ross 308 females were used in a set of four independent experiments. The insects Gryllodes sigillatus, Shelfordella lateralis, Gryllus assimilis, Tenebrio molitor and Hermetia illucens were applied in amounts that varied from 0.05 to $0.2 \%$. In general, the application of insect meals to the diets of broilers did not affect their growth performance over the experimental period. However, the $0.2 \%$ additions of $T$. molitor and $H$. illucens increased feed intake at days 15-35 $(P=0.011)$ and the entire period of feeding (days 1-35; $P=0.018$ ) (Experiment 3). Moreover, in Experiment 4 the supplementation of $0.2 \%$ of $S$. lateralis improved body weight gain (days 11-21 and 1-21), feed intake (days $1-10$ and 1-21) and feed conversion ratio (days 1-21). The addition of insect meals reduced the $\mathrm{pH}$ value of digesta in the crop (Experiments 1 and 2) and in the caeca (Experiment 2). Supplementation with $H$. illucens caused the most significant effect on the microbiota populations in the crop, ileum and caeca (Experiment 3). However, at the higher levels of S. lateralis addition to the diets of broilers, the counts of selected microbiota in the crop and ileum increased (Experiment 4). These results indicate that the application of the insect full-fat meals in relatively small amounts can affect the microbiota composition in the gastrointestinal tract of broiler chickens.
\end{abstract}

\section{Introduction}

Insects are a natural source of protein, fat and other nutrients for omnivorous species of poultry in the wild. Furthermore, invertebrates play a crucial role in the survival of young poultry, which is reduced in habitats with low insect availability.
It is well-documented that wild birds, including turkeys, need approximately $60 \%$ of their diet to come from insects during the first period of life (Rumble and Anderson, 1996), and the chicks of ring-neck pheasants are fully dependent on insects and animal matter intake during the first 3 weeks of life (Loughrey, 1951). 
The nutritive value of insects is species- and stage-dependent. The crude protein content varies from 38 to $76 \%$, whereas crude fat ranges between 14 and 43\% (Józefiak et al., 2016). To date, in most research, the administration of invertebrates as a replacement for soyabean meal or fish meal in diets has produced satisfactory results (Wang et al., 2005; Hwangbo et al., 2009; Bovera et al., 2015; Maurer et al., 2015). The inclusion of $25 \%$ housefly larvae meal in the diet of broiler chickens resulted in better growth performance in comparison with the same amount of fish meal (Pretorius, 2011). Similar results were found by Awoniyi et al. (2003), and the substitution of $25 \%$ fish meal with insect meal showed the most efficient results in the case of average weekly gain (WG) and protein efficiency ratio (PER).

Currently, to the best of our knowledge, the effects of full-fat insect meals supplemented to diets in relatively small amounts, i.e. $0.05-0.2 \%$, on broiler chicken growth performance and on the populations of microbiota in the gastrointestinal tract (GIT) have not been investigated.

Insects are also known as a potential source of antimicrobial peptides (AMP) with activities against both Gram-positive and Gram-negative bacteria, which may be exploited in livestock production (Józefiak and Engberg, 2017). AMPs are considered growth and health promoters with modulating effects on the intestinal microbiome and do not result in the development of natural bacterial resistance (Wen and He, 2012; Choi, 2013a,b; Xiao, 2015; Józefiak and Engberg, 2017). Therefore, the aim of the present study was to examine the effect of the application of full-fat insect meals as a feed additive $(0.05-0.2 \%)$ 'on top' of complete diets on the growth performance and GIT microbiota composition of broiler chickens.

\section{Material and methods}

\section{Birds and diets}

According to Polish law and EU directive (No 2010/63/EU), the experiments conducted within the study do not require the approval of the Local Ethical Committee for Experiments on Animals in Poznań (Poland).

Four independent in vivo experiments using different full-fat insect meals as a supplement for feeding broiler chickens were conducted. In the first experiment, 480 day-old, female ROSS 308 chickens obtained from a commercial hatchery were randomly distributed into 6 treatments using 8 replicate pens per group and 10 birds per pen.
The following insect species were used: Gryllodes sigillatus (Walker, 1869), Shelfordella lateralis (Walker, 1868), the imago or nymphal stage of Gryllus assimilis (Fabricius, 1775), Tenebrio molitor (Linnaeus, 1758) and Hermetia illucens (Linnaeus, 1758). The following treatments were applied:

Experiment 1: NC - negative control (without additives); PC - positive control (salinomycin, $60 \mathrm{mg} \cdot \mathrm{kg}^{-1} \mathrm{diet}$ ); GS10 $-\mathrm{NC}+0.1 \%$ of G. sigillatus; SL10 $-\mathrm{NC}+0.1 \%$ of. S. lateralis; GA $10-\mathrm{NC}+$ $0.1 \%$ of G. assimilis, imago stage; and $\mathrm{GA}_{\mathrm{s}} 10-$ $\mathrm{NC}+0.1 \%$ of $G$. assimilis, nymphal stage;

Experiment 2: NC - negative control (without additives); $\mathrm{PC}$ - positive control (salinomycin, $60 \mathrm{mg} \cdot \mathrm{kg}^{-1}$ diet); GS20 $-\mathrm{NC}+0.2 \%$ of G. sigillatus; $\mathrm{SL} 20-\mathrm{NC}+0.2 \%$ of S. lateralis; $\mathrm{GA}_{\mathrm{I}} 20-\mathrm{NC}+$ $0.2 \%$ of $G$. assimilis, imago stage; and $\mathrm{GA}_{\mathrm{s}} 20-$ $\mathrm{NC}+0.2 \%$ of $G$. assimilis, nymphal stage;

Experiment 3: $\mathrm{NC}$ - negative control (without additives); SL20 - NC $+0.2 \%$ of S. lateralis; $\mathrm{TM} 20-\mathrm{NC}+0.2 \%$ of $T$. molitor; and HI $20-\mathrm{NC}+$ $0.2 \%$ of $H$. illucens;

Experiment 4: $\mathrm{NC}$ - negative control (without additives); $\mathrm{PC}$ - positive control (salinomycin, $60 \mathrm{mg} \cdot \mathrm{kg}^{-1}$ additives diet); SL05- NC $+0.05 \%$ of S. lateralis; SL10 - NC $+0.1 \%$ of S. lateralis; and $\mathrm{SL} 20-\mathrm{NC}+0.2 \%$ of $S$. lateralis.

All insect species used in the current studies were obtained from commercial source (HiProMine S.A., Robakowo, Poland) in the form of full-fat meals, finely ground and air-dried at $55^{\circ} \mathrm{C}$.

The first trial was conducted to investigate the growth performance, i.e. body weight gain (BWG), feed intake (FI) and feed conversion ratio (FCR). Additionally, $\mathrm{pH}$ values in the crop, ileal and caecal digesta were measured. Birds were maintained in floor pens $(1 \times 1 \mathrm{~m})$ for 35 days. The stock density was based on 10 birds per $\mathrm{m}^{2}$. The housing conditions were the same in all experiments.

The second experiment was conducted with the same experimental design as that in the first, but this trial differed in the amount of insect added, which was doubled $(0.2 \%)$ compared to the first trial. The number of birds, experimental conditions and the measurements were the same as in the first experiment.

In the third trial, 400 day-old female ROSS 308 chickens were used. Birds were placed into 4 treatments containing 10 replicates per group and 10 birds per pen. S. lateralis, T. molitor and H. illucens were used at $0.2 \%$. The growth performance parameters and the $\mathrm{pH}$ values in the digesta were measured as in the first trial. Additionally, populations of microbiota were determined in the crop, ileal and caecal digesta by fluorescent in situ hybridization (FISH). 
In the fourth experiment, 500 day-old female ROSS 308 chickens were distributed into 5 groups with 10 replicate pens of 10 birds each. The experiment was run for 41 days, and $0.05,0.1$ and $0.2 \%$ of S. lateralis was added based on the results obtained in the third experiment. The growth performance parameters and the microbiota populations in the same three GIT segments were evaluated.

The compositions of the experimental diets used in all experiments are shown in Table 1. Diets for each period were formulated to be isonitrogenous and isocaloric. The diets were prepared in a mash form; all raw materials were ground by disc mill (Skiold A/S, Sæby, Denmark) at a 2.5-mm disc dis-

Table 1. Basal diet composition and nutritive value

\begin{tabular}{lccc}
\hline \multirow{2}{*}{ Indices } & \multicolumn{3}{l}{ Basal diet } \\
\cline { 2 - 4 } & starter & grower & finisher \\
\hline Ingredients, $\mathrm{g} \cdot \mathrm{kg}^{-1}$ & & & \\
wheat & 226.1 & 330.6 & 150.0 \\
maize grain & 201.7 & 111.8 & 310.7 \\
rye & 150.0 & 150.0 & 150.0 \\
soyabean meal & 224.7 & 150.2 & 183.2 \\
rapeseed meal & 100.0 & 150.0 & 100.0 \\
fish meal & 15.0 & 19.2 & 20.0 \\
pig lard & 49.5 & 65.0 & 65.0 \\
vitamin-mineral premix & 3.0 & 3.0 & 3.0 \\
phosphate 2-Ca & 17.1 & 10.5 & 7.8 \\
limestone & 3.3 & 2.3 & 3.4 \\
NaCl & 1.3 & 1.4 & 1.1 \\
sodium carbonate & 1.7 & 1.2 & 1.5 \\
L-lysine-HCl & 3.2 & 2.9 & 2.2 \\
methionine (88\% liquid) & 3.0 & 2.0 & 2.2 \\
L-threonine & 0.7 & 0.1 & 0.1 \\
Calculated nutritive value, $\mathrm{g} \cdot \mathrm{kg}^{-1}$ & & & \\
crude protein & 208 & 198 & 190 \\
crude fat & 68.9 & 83.0 & 87.1 \\
crude fibre & 33.4 & 37.0 & 32.5 \\
Na & 1.5 & 1.4 & 1.4 \\
Ca & 8.5 & 7.0 & 6.5 \\
P & 7.8 & 6.9 & 6.1 \\
lysine & 12.9 & 11.8 & 11.2 \\
methionine & 5.9 & 5.0 & 5.0 \\
methionine + cystine & 9.5 & 8.7 & 8.4 \\
threonine & 8.4 & 7.4 & 7.2 \\
AMEn ${ }^{3}$, MJ $\mathrm{kg}^{-1}$ & 12.55 & 12.97 & 13.28 \\
\hline
\end{tabular}

${ }^{1}$ starter diets were offered to all birds from days 1 to 8 (Experiments 1 and 2), 1 to 10 (Experiment 4), or 1 to 14 of age (Experiment 3); grower diets were fed between days 9 to 21 (Experiments 1 and 2), 11 to 21 (Experiment 4), or 15 to 21 of age (Experiment. 3); finisher diets were used from days 22 to 35 (Experiment 1, 2 and 3 ) or to 41 of age (Experiment 4$) ;{ }^{2}$ provided per kilogram of diet: IU: vit. A 11 166, cholecalciferol 2500; mg: vit. E 80, menadione 2.50, vit. $B_{12} 0.02$, folic acid 1.17 , choline 379 , D-pantothenic acid 12.50 , riboflavin 7.0 , niacin 41.67 , thiamine 2.17, D-biotin 0.18 , pyridoxine 4.0 , ethoxyquin 0.09, $\mathrm{Mn}\left(\mathrm{MnO}_{2}\right) 73, \mathrm{Zn}(\mathrm{ZnO}) 55, \mathrm{Fe}\left(\mathrm{FeSO}_{4}\right)$ 45, $\mathrm{Cu}$ $\left(\mathrm{CuSO}_{4}\right)$ 20, I $\left(\mathrm{Cal}_{2} \mathrm{O}_{6}\right)$ 0.62, Se $\left(\mathrm{Na}_{2} \mathrm{SeO}_{3}\right)$ 0.3; ${ }^{3} \mathrm{AMEn}$ - apparent metabolizable energy corrected to zero nitrogen balance tance, mixed without any heat treatment and fed $a d$ libitum to the birds. Starter diets were offered to all birds from days 1 to 8 (Experiments 1 and 2), 1 to 10 (Experiment 4), or 1 to 14 of age (Experiment 3); grower diets were fed between days 9 to 21 (Experiments 1 and 2), 11 to 21 (Experiment 4), or 15 to 21 of age (Experiment. 3); finisher diets were used from days 22 to 35 (Experiment 1, 2 and 3) or to 41 of age (Experiment 4). The experimental diets were designed to provoke GIT colonization by Clostridium perfringens due to the use of viscous cereals (wheat/rye), animal fat (pig lard) and fish meal. Furthermore, no exogenous enzymes were used in the studies. Insect meals were added 'on top' of the basal diets per tonne. The nutritive value of the selected insect species is shown in Table 2.

Table 2. Nutritive value of selected insect species, $\mathrm{g} \cdot \mathrm{kg}^{-1} \mathrm{DM}$

\begin{tabular}{lllllll}
\hline $\begin{array}{l}\text { Indices } \\
\text { Sigillatus }\end{array}$ & \multicolumn{2}{l}{$\begin{array}{l}\text { Shelfordel- } \\
\text { la lateralis }\end{array}$} & Gryllus assimilis & $\begin{array}{l}\text { Tenebrio } \\
\text { molitor }\end{array}$ & $\begin{array}{l}\text { Hermetia } \\
\text { illucens }\end{array}$ \\
\cline { 2 - 6 } & imago & imago & nymph & imago & larvae & larvae \\
\hline $\begin{array}{l}\text { Crude } \\
\text { protein }\end{array}$ & $613 \pm 49$ & $546 \pm 25$ & $638 \pm 29$ & $564 \pm 25563 \pm 25$ & $404 \pm 18$ \\
$\begin{array}{l}\text { Crude } \\
\text { fat }\end{array}$ & $195 \pm 18$ & $261 \pm 23$ & $168 \pm 15$ & $238 \pm 21$ & $253 \pm 20$ & $335 \pm 30$ \\
$\begin{array}{l}\text { Crude } \\
\text { fibre }\end{array}$ & $60 \pm 6$ & $89 \pm 9$ & $94 \pm 9$ & $70 \pm 7$ & $85 \pm 8$ & $97 \pm 10$ \\
$\begin{array}{l}\text { Crude } \\
\text { ash }\end{array}$ & $65.6 \pm 5.9$ & $54.6 \pm 4.9$ & $53.6 \pm 4.8$ & $64.2 \pm 5.845 .3 \pm 1.8$ & $71.3 \pm 6.4$ \\
\hline
\end{tabular}

\section{Data and sample collection}

The growth performance parameters in each experiment were measured using a replicate pen serving as the experimental unit. The FI and BWG of the chickens were determined on days 8 and 35 (Experiments 1 and 2) or 14 and 35 (Experiment 3) or 10, 21 and 41 (Experiment 4). In all trials, on day 28 from each experimental group, 10 randomly selected chickens were killed by cervical dislocation. In the first and second trial, one additional randomlychosen bird was chosen from two separate replications. For analyses of the gastrointestinal contents (microbiota population and $\mathrm{pH}$ ), the digesta of crop, ileum and caeca from individual birds (10 per treatment) were collected by gentle squeezing. A part $(5 \mathrm{~g})$ of each digesta sample was immediately packed and sealed in sterilized plastic bags. Samples were stored at $-80{ }^{\circ} \mathrm{C}$ for the analysis of the microbiota composition by FISH of single bacterial cells. The digesta $\mathrm{pH}$ value was measured using a combined glass and reference electrode $(\mathrm{pH} 100 \mathrm{~L}$; VWR International, Leuven, Belgium). For $\mathrm{pH}$ value determining, as well as microbiota counts, the experimental unit was 1 bird randomly chosen from each replication (10 birds per treatment in total). 


\section{Microbial community analysis by fluorescent in situ hybridization (FISH)}

All details of sample preparation and FISH analyses for bacteria enumeration from crop, ileal and caecal digesta are described in Józefiak et al. (2013). Briefly, samples of the gastrointestinal content taken during bird dissection were immediately frozen and stored in $-80{ }^{\circ} \mathrm{C}$. For FISH analysis, $100 \mu \mathrm{l}$ of digesta were diluted in phosphate-buffered saline (PBS) and pipetted onto $0.22 \mu \mathrm{m}$ polycarbonate filters (K02BP02500, Frisenette ApS, Knebel, Denmark) and vacuumed (LABOPORT Vacuum pomp, KNF, Freiburg, Germany). After vacuuming, the filters were transferred onto cellulose discs for dehydration in an ethanol series $(50,80$ and $96 \%$, 3 min each). For each sample, a series of identical filters was prepared to allow the determination of optimal hybridization. The oligonucleotide probes used in these studies are described in detail in Table 3 (Józefiak et al., 2016). Hybridizations were carried out in $50 \mu \mathrm{l}$ of hybridization buffer $(0.9 \mathrm{M} \mathrm{NaCl}$; $20 \mathrm{mM}$ Tris $/ \mathrm{HCl}, \mathrm{pH}$ 7.2; 0.01\% SDS) containing the oligonucleotides probes. After hybridization, filters were washed with washing buffer $(20 \mathrm{mM}$ Tris/ $\mathrm{HCl}, \mathrm{pH} 7.2 ; 0.01 \% \mathrm{SDS} ; 5 \mathrm{mM}$ EDTA) for $20 \mathrm{~min}$ at $48{ }^{\circ} \mathrm{C}$. The filters were rinsed gently in distilled water, air-dried, and mounted on object glasses with VectaShield (No. H-1000, Vector Laboratories, Burlingame, CA, USA) anti-fading agent containing DAPI (4',6-diamidino-2-phenylindole). To distinguish the total count (DAPI) of bacteria from other particles in GIT content samples, the filters were left in $4{ }^{\circ} \mathrm{C}$ for $1 \mathrm{~h}$ in the dark until visualized using a Microscope Axio Imager M2 (Carl Zeiss, Thornwood, NY, USA).

Table 3. Oligonucleotide probes used for intestinal microbiota analyses using fluorescent in situ hybridization (FISH) (Józefiak et al. (2016))

\begin{tabular}{|c|c|c|}
\hline Target & Probe & Sequence (from 5' to $3^{\prime}$ ) \\
\hline $\begin{array}{l}\text { Bacteroides-Prevotella } \\
\text { cluster }\end{array}$ & Bacto303 & CCAATGTGGGGGACCTT \\
\hline Enterobacteriaceae & Enter1432 & CTTTTGCAACCCACT \\
\hline $\begin{array}{l}\text { Lactobacillus spp./ } \\
\text { Enterococcus spp. }\end{array}$ & Lab158 & GGTATTAGCAYCTGTTTCCA \\
\hline $\begin{array}{l}\text { Clostridium coccoides- } \\
\text { Eubacterium rectale cluster }\end{array}$ & Erec482 & GCTTCTTAGTCARGTACCG \\
\hline Clostridium leptum subgroup & Clept1240 & GTTTTRTCAACGGCAGTC \\
\hline $\begin{array}{l}\text { Streptococus spp./ } \\
\text { Lactococcus spp. }\end{array}$ & Strc493 & GTTAGCCGTCCCTTTCTGG \\
\hline
\end{tabular}

\section{Statistical analyses}

All experiments used a completely randomized design, and data were tested using the GLM proce- dure of the SAS statistical software package ver. 9.4 (SAS Institute Inc., Cary, NC, USA). In all experiments, means were separated using Duncan's tests following a one-way analysis of variance (ANOVA) based on the following equation:

$$
\mathrm{Y}_{\mathrm{ij}}=\mu+\alpha_{\mathrm{i}}+\delta_{\mathrm{ij}}
$$

where: $Y_{i j}$-observed dependent variable; $\mu$-overall mean; $\alpha_{i}-$ effect of treatment; and $\delta_{i j}$-random error. In cases in which the overall effect was significant $(P \leq 0.05)$, means were compared pairwise (pdiff). The results are given as the least squares means with a pooled standard deviation.

\section{Results}

\section{Experiments 1 and 2}

The performance of the birds (Tables 4 and 5) fed diet with full-fat insect meal supplementation did not differ from $\mathrm{NC}$ and $\mathrm{PC}$ groups, irrespective of the supplementation amount $(0.1$ or $0.2 \%)$. However, the addition of both 0.1 and $0.2 \%$ of $G$. assimilis (nymphal stage) decreased the $\mathrm{pH}$ value of the digesta in the crop (Experiment 1, $P=0.003$; Experiment 2, $P=0.005$; Table 6), and the addition of $0.1 \%$ of $G$. sigillatus caused a similar effect $(P=0.003)$. Moreover, supplementation with $0.2 \%$ of $S$. lateralis reduced the $\mathrm{pH}$ in the crop and caeca compared with that in $\mathrm{NC}$ and $\mathrm{PC}$ groups and resulted in the lowest caecal digesta $\mathrm{pH}(P=0.002)$ among all treatments.

Table 4. Growth performance of broiler chickens fed diet with $0.1 \%$ of insect meals addition (Experiment 1)

\begin{tabular}{|c|c|c|c|c|c|c|c|}
\hline \multirow{2}{*}{ Indices $^{1}$} & \multicolumn{6}{|c|}{ Treatments $^{2}$} & \multirow{2}{*}{ SEM ${ }^{3} P$-value } \\
\hline & $\mathrm{NC}$ & PC & GS10 & SL10 & GA,10 & $\mathrm{GA}_{\mathrm{S}} 10$ & \\
\hline \multicolumn{8}{|l|}{ BWG, g } \\
\hline days $1-8$ & 153 & 156 & 158 & 153 & 156 & 158 & 1.520 .885 \\
\hline 9-35 & 1868 & 1937 & 1848 & 1958 & 1901 & 1841 & $22.02 \quad 0.575$ \\
\hline $1-35$ & 2021 & 2093 & 2006 & 2111 & 2057 & 1999 & $22.23 \quad 0.614$ \\
\hline \multicolumn{8}{|c|}{$\mathrm{Fl}, \mathrm{g}$} \\
\hline days $1-8$ & 205 & 205 & 208 & 210 & 203 & 203 & 2.030 .877 \\
\hline $9-35$ & 2980 & 2975 & 2954 & 3071 & 3052 & 3001 & 17.740 .348 \\
\hline $1-35$ & 3184 & 3180 & 3162 & 3281 & 3255 & 3203 & $18.44 \quad 0.380$ \\
\hline \multicolumn{8}{|c|}{$\mathrm{FCR}, \mathrm{g} \cdot \mathrm{g}^{-1}$} \\
\hline days $1-8$ & 1.35 & 1.33 & 1.32 & 1.37 & 1.31 & 1.29 & 0.020 .745 \\
\hline $9-35$ & 1.60 & 1.55 & 1.61 & 1.58 & 1.61 & 1.64 & 0.010 .556 \\
\hline $1-35$ & 1.58 & 1.53 & 1.58 & 1.57 & 1.58 & 1.61 & 0.010 .586 \\
\hline
\end{tabular}

${ }^{1}$ BWG - body weight gain, $\mathrm{FI}$ - feed intake, FCR - feed conversion ratio; ${ }^{2}$ treatments: NC - negative control (without additives), PC - salinomycin (60 mg $\cdot \mathrm{kg}^{-1}$ diet), GS10 $-0.1 \%$ of Gryllodes sigillatus, SL10 $-0.1 \%$ of Shelfordella lateralis, GA,10 - $0.1 \%$ of Gryllus assimilis (imago stage), $\mathrm{GA}_{\mathrm{s}} 10-0.1 \%$ of Gryllus assimilis (nymphal stage) (in all groups insect meals were supplemented 'on top'); ${ }^{3}$ SEM - standard error of mean 
Table 5. Growth performance of broiler chickens fed diets with $0.2 \%$ of insect meals addition (Experiment 2)

\begin{tabular}{|c|c|c|c|c|c|c|c|c|}
\hline \multirow{2}{*}{ Indices ${ }^{1}$} & \multicolumn{6}{|c|}{ Treatments $^{2}$} & \multirow{2}{*}{\multicolumn{2}{|c|}{ SEM ${ }^{3} P$-value }} \\
\hline & $\mathrm{NC}$ & PC & GS20 & SL20 & GA20 & $\mathrm{GA}_{\mathrm{s}} 20$ & & \\
\hline \multicolumn{9}{|l|}{ BWG, g } \\
\hline & 155 & 155 & 153 & 157 & 157 & 151 & 1.46 & 0.846 \\
\hline 9-35 & 1884 & 1981 & 1848 & 1846 & 1834 & 1889 & .72 & 0.166 \\
\hline $1-$ & 2038 & 2136 & 2001 & 2003 & 1991 & 2040 & 17.84 & 0.181 \\
\hline \multicolumn{9}{|l|}{$\mathrm{Fl}, \mathrm{g}$} \\
\hline & 203 & 204 & 205 & 212 & 212 & 198 & 1.91 & 0.276 \\
\hline $9-35$ & 3010 & 3003 & 2987 & 2978 & 2982 & 2965 & 15.39 & 0.973 \\
\hline $1-35$ & 3213 & 3207 & 3193 & 3190 & 3194 & 3164 & 15.73 & 0.970 \\
\hline \multicolumn{9}{|c|}{$F C R, g \cdot g^{-1}$} \\
\hline & 1.32 & $2 \quad 1.33$ & 1.34 & 1.35 & 1.35 & 1.32 & 0.02 & 0.980 \\
\hline 9 & 1.60 & 1.52 & 1.62 & 1.62 & 1.63 & 1.57 & & 0.088 \\
\hline $1-35$ & 1.58 & $8 \quad 1.51$ & $1 \quad 1.60$ & 1.60 & 1.61 & 1.55 & 0.01 & 0.076 \\
\hline \multicolumn{9}{|c|}{$\begin{array}{l}{ }^{1} \text { see Table } 4 ;{ }^{2} \text { treatments: } \mathrm{NC} \text { - negative control (without additives), } \\
\mathrm{PC}-\text { salinomycin ( } 60 \mathrm{mg} \cdot \mathrm{kg}^{-1} \text { diet), GS20 - } 0.2 \% \text { of Gryllodes } \\
\text { sigillatus, SL20 - } 0.2 \% \text { of Shelfordella lateralis, GA, } 20-0.2 \% \text { of } \\
\text { Gryllus assimilis (imago stage), GA } 20-0.2 \% \text { of Gryllus assimilis } \\
\text { (nymphal stage) (in all groups insect meals were supplemented 'on } \\
\text { top'); }{ }^{3} \mathrm{SEM} \text { - standard error of mean }\end{array}$} \\
\hline
\end{tabular}

Table 6. Values of $\mathrm{pH}$ in the crop, ileum and caeca digesta after additions of 0.1 or $0.2 \%$ of insect meals (Experiments 1 and 2)

\begin{tabular}{|c|c|c|c|c|c|c|c|c|}
\hline & & & Expe & riment 1 & & & & \\
\hline Digest & & & Trea & tments $^{1}$ & & & SEM $^{3}$ & $P$-value \\
\hline & $\overline{\mathrm{NC}}$ & PC & GS10 & SL10 & $\mathrm{GA}_{1} 10$ & $\mathrm{GA}_{\mathrm{s}} 10$ & & \\
\hline Crop & $5.49^{a}$ & $5.48^{\mathrm{a}}$ & $4.91^{b}$ & $5.15^{\mathrm{ab}}$ & $5.10^{\mathrm{ab}}$ & $4.84^{b}$ & 0.06 & 0.003 \\
\hline Ileum & 6.25 & 6.54 & 5.98 & 6.53 & 6.61 & 6.59 & 0.08 & 0.148 \\
\hline Caeca & 6.30 & 6.19 & 6.13 & 5.89 & 6.18 & 5.94 & 0.05 & 0.120 \\
\hline & & & $\begin{array}{l}\text { Expe } \\
\text { Trea }\end{array}$ & $\begin{array}{l}\text { iment } 2 \\
\text { tments }\end{array}$ & & & & \\
\hline & $\overline{\mathrm{NC}}$ & PC & GS20 & SL20 & GA,20 & $\mathrm{GA}_{\mathrm{s}} 20$ & & \\
\hline Crop & $5.48^{a}$ & $5.48^{a}$ & $5.33^{\mathrm{ab}}$ & $4.97^{\mathrm{bc}}$ & $5.07^{\mathrm{abc}}$ & $4.88^{c}$ & 0.06 & 0.005 \\
\hline Ileum & 6.25 & 6.54 & 6.35 & 6.56 & 6.62 & 6.42 & 0.07 & 0.691 \\
\hline Caeca & $6.30^{\mathrm{ab}}$ & $6.19^{\mathrm{ab}}$ & $6.42^{\mathrm{a}}$ & $5.80^{c}$ & $6.16^{\mathrm{ab}}$ & $5.98^{\mathrm{bc}}$ & 0.05 & 0.002 \\
\hline
\end{tabular}

Table 7. Growth performance of broiler chickens (Experiment 3)

\begin{tabular}{|c|c|c|c|c|c|c|}
\hline \multirow{2}{*}{ Indices $^{1}$} & \multicolumn{4}{|c|}{ Tretments ${ }^{2}$} & \multirow{2}{*}{$\mathrm{SEM}^{3}$} & \multirow{2}{*}{$P$-value } \\
\hline & $\mathrm{NC}$ & SL20 & TM20 & $\mathrm{HI} 2 \mathrm{O}$ & & \\
\hline \multicolumn{7}{|l|}{ BWG, $g$} \\
\hline days $1-14$ & 372 & 379 & 383 & 387 & 2.44 & 0.181 \\
\hline $15-35$ & 1697 & 1697 & 1744 & 1715 & 10.93 & 0.196 \\
\hline $1-35$ & 2069 & 2076 & 2127 & 2101 & 10.52 & 0.193 \\
\hline \multicolumn{7}{|l|}{$\mathrm{FI}, \mathrm{g}$} \\
\hline days $1-14$ & 542 & 532 & 535 & 545 & 3.52 & 0.556 \\
\hline $15-35$ & $2553^{b}$ & $2592^{\mathrm{ab}}$ & $2676^{a}$ & $2665^{\mathrm{a}}$ & 15.99 & 0.011 \\
\hline $1-35$ & $3094^{b}$ & $3124^{a b}$ & $3211^{a}$ & $3210^{a}$ & 16.90 & 0.018 \\
\hline \multicolumn{7}{|c|}{$\mathrm{FCR}, \mathrm{g} \cdot \mathrm{g}^{-1}$} \\
\hline days $1-14$ & 1.46 & 1.41 & 1.40 & 1.41 & 0.01 & 0.122 \\
\hline $15-35$ & $1.51^{\mathrm{b}}$ & $1.53^{\mathrm{ab}}$ & $1.53^{\mathrm{ab}}$ & $1.55^{\mathrm{a}}$ & 0.01 & 0.014 \\
\hline $1-35$ & 1.50 & 1.51 & 1.51 & 1.53 & 0.01 & 0.095 \\
\hline
\end{tabular}

${ }^{1}$ see Table 4; ${ }^{2}$ treatments: NC - negative control (without additives), SL20 $-0.2 \%$ of Shelfordella lateralis, TM20 $-0.2 \%$ of Tenebrio molitor, $\mathrm{HI} 20-0.2 \%$ of Hermetia illucens (in all groups insect meals were supplemented 'on top'); ${ }^{3}$ SEM - standard error of mean; ab - means with different superscripts within a row are significantly different at $P \leq 0.05$

\section{Experiment 3}

Supplementation with $T$. molitor and $H$. illucens increased the feed intake of the birds at days 15-35 $(P=0.011)$ and for the entire trial $(P=0.018$; Table 7). In the HI20 treatment, the FCR was impaired in comparison with that in the NC group at days 15-35 $(P=0.014)$, but no significant differences were observed for the entire trial (days 1-35). In the crop, statistically significant changes in microbiota were observed (Table 8). In the T. molitor treatment, the lowest counts of the Bacteroides-Prevotella cluster were observed $(P=0.001)$.

Table 8. Selected microbiota counts in the crop, ileal and caecal digesta determined by DAPI staining and fluorescent in situ hybridization, log cell number $\cdot \mathrm{g}^{-1}$ of digesta (Experiment 3 )

\begin{tabular}{|c|c|c|}
\hline \multirow{2}{*}{ Indices } & \multicolumn{2}{|l|}{ Treatments $^{1}$} \\
\hline & $\begin{array}{llll}\text { NC } & \text { SL20 } & \text { TM2O } & \text { HI20 }\end{array}$ & SEIVI $\left.\right|^{-}$ \\
\hline
\end{tabular}

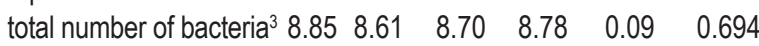

$\begin{array}{lllllll}\text { Bacteroides-Prevotella } & 8.48^{\mathrm{a}} & 8.46^{\mathrm{a}} & 8.23^{\mathrm{b}} & 8.41^{\mathrm{a}} & 0.02 & 0.001\end{array}$

cluster

$\begin{array}{llllll}\text { Clostridium leptum } & 8.25^{\mathrm{bc}} 8.42^{\mathrm{a}} & 8.30^{\mathrm{ab}} & 8.16^{\mathrm{c}} & 0.03 & 0.015 \\ \text { subgroup } & & \end{array}$

Streptococcus spp./ $\quad 7.83 \quad 8.19 \quad 8.04 \quad 7.91 \quad 0.09 \quad 0.741$

Lactococcus spp.

Clostridium coccoides-

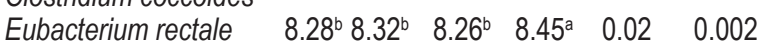

cluster

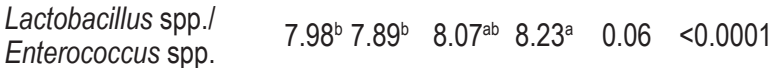

lleum

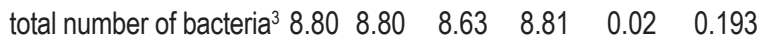

$\begin{array}{llllllll}\text { Bacteroides-Prevotella } & 8.34 & 8.47 & 8.36 & 8.55 & 0.01 & <0.001\end{array}$

cluster

Clostridium leptum

subgroup

$\begin{array}{llllll}8.29 & 8.37 & 8.36 & 8.34 & 0.01 & 0.081\end{array}$

$\begin{array}{lllllll}\text { Streptococcus spp./ } & 8.23 & 8.24 & 8.24 & 8.36 & 0.03 & 0.001\end{array}$

Lactococcus spp.

Clostridium coccoides-

Eubacterium rectale $\quad 8.07^{\mathrm{c}} 8.16^{\mathrm{b}} \quad 8.20^{\mathrm{ab}} \quad 8.28^{\mathrm{a}} \quad 0.01<0.001$ cluster

Lactobacillus spp./

Enterococcus spp.

Caeca

total number of bacteria ${ }^{3} 9.77 \quad 9.73 \quad 9.56 \quad 9.84 \quad 0.04 \quad<0.0001$

$\begin{array}{lllllll}\text { Bacteroides-Prevotella } & 8.61^{\mathrm{c}} & 8.81^{\mathrm{b}} & 8.60^{\mathrm{c}} & 9.05^{\mathrm{a}} & 0.09 & <0.0001 \\ \text { cluster } & & \end{array}$

Clostridium leptum

subgroup

$\begin{array}{llllll}8.28 & 8.32 & 8.43 & 8.45 & 0.07 & 0.061\end{array}$

Streptococcus spp./ $\quad 8.17^{\mathrm{b}} 8.33^{\mathrm{b}} \quad 8.21^{\mathrm{b}} \quad 8.93^{\mathrm{a}} \quad 0.20<0.0001$ Lactococcus spp.

Clostridium coccoides-

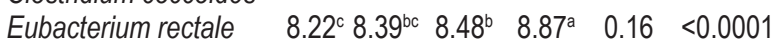
cluster

Lactobacillus spp./

Enterococcus spp.

$8.27^{\mathrm{bc}} 8.54^{\mathrm{ab}} \quad 8.17^{\mathrm{c}} \quad 8.60^{\mathrm{a}} \quad 0.05 \quad 0.007$

${ }^{1}$ see Table $7 ;{ }^{2}$ SEM - standard error of mean; ${ }^{3}$ total number of bacteria determined by 4',6-diamidino-2-phenylindole (DAPI) staining; $\mathrm{abc}$ - means with different superscripts within a row are significantly different at $P \leq 0.05$ 
In comparisson with the SL20 and TM20 treatments, HI20 lowered the Clostridium leptum subgroup counts and increased those of the Clostridium coccoides-Eubacterium rectale cluster. Moreover, in the HI20 treatment, the highest numbers of Lactobacillus spp./Enterococcus spp. were observed compared with those of the NC and SL20 treatments. In comparison with the negative control, the addition of selected insect full-fat meals increased numbers of Clostridium coccoides-Eubacterium rectale cluster in the ileal digesta $(P<0.001)$. The lowest Lactobacillus spp./Enterococcus spp. counts were in the HI20 treatment, whereas an increase was observed in the TM20 treatment. In the caecal digesta, counts of Bacteroides-Prevotella, Clostridium coccoides-Eubacterium rectale clusters and Streptococcus spp./Lactococcus spp. were the highest in the HI20 group. Hermetia illucens addition also resulted in increased counts of Lactobacillus spp./Enterococcus spp. compared with those in the control and TM20 groups.

\section{Experiment 4}

At days 11-21 and 1-21, supplementation of $0.2 \%$ full-fat $S$. lateralis meal improved BWG (Table 9). The final BWG (days 1-41) in the SL20

Table 9. Growth performance of broiler chickens (Experiment 4)

\begin{tabular}{|c|c|c|c|c|c|c|c|}
\hline \multirow{2}{*}{ Indices ${ }^{1}$} & \multicolumn{5}{|c|}{ Treatments $^{2}$} & \multirow{2}{*}{ SEM $^{3}$} & \multirow{2}{*}{$P$-value } \\
\hline & $\overline{N C}$ & PC & SL05 & SL10 & SL20 & & \\
\hline \multicolumn{8}{|l|}{ BWG, $g$} \\
\hline days $1-10$ & 181 & 177 & 178 & 184 & 189 & 1.56 & 0.089 \\
\hline $11-21$ & $561^{b}$ & $552^{b}$ & $560^{b}$ & $564^{b}$ & $588^{a}$ & 3.75 & 0.025 \\
\hline $1-21$ & $740^{\mathrm{b}}$ & $727^{b}$ & $737^{b}$ & $747^{\mathrm{ab}}$ & $776^{a}$ & 5.10 & 0.028 \\
\hline $22-41$ & 2002 & 2038 & 2029 & 2031 & 2064 & 8.91 & 0.295 \\
\hline $1-41$ & 2743 & 2765 & 2766 & 2778 & 2840 & 11.89 & 0.099 \\
\hline \multicolumn{8}{|l|}{$\mathrm{Fl}, \mathrm{g}$} \\
\hline days $1-10$ & $239^{b}$ & $251^{\mathrm{ab}}$ & $244^{\mathrm{ab}}$ & $251^{\mathrm{ab}}$ & $257^{a}$ & 2.04 & 0.041 \\
\hline $11-10$ & 828 & 827 & 831 & 848 & 867 & 5.25 & 0.067 \\
\hline $1-21$ & $1067^{b}$ & $1078^{b}$ & $1075^{b}$ & $1100^{\mathrm{ab}} 1$ & $1124^{a}$ & 6.64 & 0.041 \\
\hline $22-41$ & 3452 & 3485 & 3484 & 3517 & 3545 & 14.25 & 0.299 \\
\hline $1-41$ & 4519 & 4564 & 4560 & 4617 & 4669 & 19.39 & 0.123 \\
\hline $\begin{array}{l}F C R, g \cdot g^{-1} \\
\text { days } 1-10\end{array}$ & $1.32^{\mathrm{b}}$ & $1.43^{a}$ & $1.37^{a b}$ & b $1.37^{a b}$ & $1.36^{\mathrm{ab}}$ & 0.0111 & 0.048 \\
\hline $11-21$ & 1.48 & 1.50 & 1.48 & 1.50 & 1.47 & 0.0049 & 0.218 \\
\hline $1-21$ & $1.44^{\mathrm{b}}$ & $1.48^{a}$ & a $1.46^{\mathrm{ab}}$ & b $1.47^{a b}$ & $1.45^{b}$ & 0.0051 & 0.045 \\
\hline $22-42$ & 1.72 & 1.71 & 1.72 & 1.73 & 1.72 & 0.0051 & 0.780 \\
\hline $1-41$ & 1.65 & 1.65 & 1.65 & 1.66 & 1.64 & 0.0039 & 0.687 \\
\hline
\end{tabular}

${ }^{1}$ see Table $4 ;{ }^{2}$ treatments: NC - negative control (without additives), PC - salinomycin (60 mg $\cdot \mathrm{kg}^{-1}$ diet), SL05 $-0.05 \%$ of Shelfordella lateralis, SL10 $-0.1 \%$ of Shelfordella lateralis, SL20 $-0.2 \%$ of Shelfordella lateralis (in all groups insect meals were supplemented 'on top'); ${ }^{3}$ SEM - standard error of mean; ${ }^{\text {ab }}$ - means with different superscripts within a row are significantly different at $P \leq 0.05$ treatment improved by approximately $3.5 \%$, although the difference was not statistically significant $(P=0.099)$. The feed intake also improved in the SL20 treatment at days 1-10 and 1-21. The FCR in the SL20 treatment at days 1-21 was better than that in the PC $(P=0.045)$ but did not differ from that in the NC.

In the crop, the highest counts of total microbiota were found in the SL20 treatment. The Clostridium leptum subgroup and Clostridium coccoides-Eubacterium rectale counts increased in all treatments supplemented with $S$. lateralis (Table 10). In the ileal digesta, for most of the microbiota populations, no statistically significant effects of $S$. lateralis meal were observed. The only changes in the microbiota were for Lactobacillus spp./Enterococcus spp., and the lowest counts were marked in the NC treatment. In the caecal digesta, no significant differences were observed.

Table 10. Selected microbiota counts in crop, ileal and caecal digesta determined by DAPI staining and fluorescent in situ hybridization (FISH), log cell number $\cdot \mathrm{g}^{-1}$ of digesta (Experiment 4 )

\begin{tabular}{ll}
\hline Indices & Tretments $^{1}$ \\
\cline { 2 - 2 } & NC PC SL05 SL10 SL20 SEM ${ }^{2} P$-value \\
\hline
\end{tabular}

\section{Crop}

total number of bacteria ${ }^{3} 9.08^{\mathrm{c}} 8.98^{\mathrm{e}} 9.15^{\mathrm{b}} 9.03^{\mathrm{d}} 9.22^{\mathrm{a}} \quad 0.01<0.0001$ Clostridium leptum subgroup

$8.06^{c} 8.04^{c} 8.19^{b} 8.27^{a} 8.30^{a} 0.01<0.0001$

Clostridium coccoides-

Eubacterium rectale $8.01^{\mathrm{c}} 8.12^{\mathrm{b}} 8.26^{\mathrm{a}} 8.32^{\mathrm{a}} 8.29^{\mathrm{a}} 0.01<0.0001$ cluster

Lactobacillus spp./

Enterococcus spp.

$\begin{array}{lllllll}8.53 & 8.60 & 8.56 & 8.34 & 8.47 & 0.01 & 0.01\end{array}$

lleum

total number of

bacteria $^{3}$

$\begin{array}{lllllll}9.10 & 9.37 & 9.30 & 9.35 & 9.36 & 0.01 & 0.21\end{array}$

Clostridium leptum

subgroup

$\begin{array}{lllllll}8.26 & 8.56 & 8.32 & 8.30 & 8.21 & 0.01 & 0.06\end{array}$

Clostridium coccoides-

$\begin{array}{llllllll}\text { Eubacterium rectale } & 8.18 & 8.42 & 8.44 & 8.30 & 8.26 & 0.01 & 0.31\end{array}$

cluster

Lactobacillus spp./

Enterococcus spp.

$8.45^{\mathrm{d}} 8.60^{\mathrm{b}} 8.58^{\mathrm{c}} 8.57^{\mathrm{c}} 8.63^{\mathrm{a}} 0.01<0.0001$

\section{Caeca}

total number of bacteria ${ }^{3} 10.2010 .1010 .1610 .1810 .07 \quad 0.004 \quad 0.22$

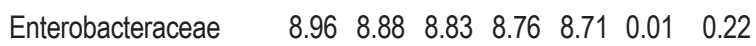

Clostridium leptum

subgroup

$\begin{array}{lllllll}9.32 & 9.35 & 9.13 & 9.09 & 9.19 & 0.01 & 0.52\end{array}$

Clostridium coccoides-

$\begin{array}{llllllll}\text { Eubacterium rectale } & 9.41 & 9.33 & 9.33 & 9.43 & 9.29 & 0.004 & 0.12\end{array}$ cluster

$\begin{array}{llllllll}\text { Lactobacillus spp./En- } & 9.52 & 9.57 & 9.41 & 9.38 & 9.42 & 0.01 & 0.32\end{array}$ terococcus spp.

${ }^{1}$ see Table $9 ;{ }^{2}$ SEM - standard error of mean; ${ }^{3}$ total number of bacteria determined by 4',6-diamidino-2-phenylindole (DAPI) staining; a-e - means with different superscripts within a row are significantly different at $P \leq 0.05$ 


\section{Discussion}

Insect meals as a novel source of nutrients have been successfully added to the diets of animals, such as broiler chickens, layers, weaned pigs, aquatic animals and rabbits (Makkar et al., 2014). In general, the data suggest that the welfare, growth performance, nutrient digestibility, intestinal morphological features, and even quality of the carcass and meat are not adversely affected by insect additions to the diet. However, the current study was aimed to analyse the potential effects of insect meals used as feed additives, in low amounts ranging from 0.05 to $0.2 \%$, added 'on top' of the diet.

In general, supplementation of the full-fat insect meals did not improve final performance results of the birds. However, the addition of $0.2 \% \mathrm{H}$. illucens and $T$. molitor increased FI without any adverse effect on the FCR, simultaneously improving BWG by 1.5 and $2.8 \%$, respectively. Whereas the $0.05 \%$ addition of $S$. lateralis had a similar effect on BWG, FI and FCR to that of the group supplemented with salinomycin, the $0.2 \%$ addition increased BWG up to $3.5 \%$ as compared with the NC.

In poultry, all segments of the GIT are colonized by different populations of microbiota (Salanitro et al., 1978; Pan and Yu, 2014; Józefiak and Engberg, 2017). To date, more than 900 bacterial species have been identified, and it is well documented that the disturbance of microbial homeostasis can have significant negative effects on intestinal health and bird performance (Stanley et al., 2014). In the current experiments, the analysed microbiota populations were chosen as gut health indicators on the basis of our earlier research (Józefiak et al., 2011, 2012, 2013, 2016; Ptak et al., 2015; Kierończyk et al., 2016; Dunislawska et al., 2017). Although it cannot be demonstrated that final performance indices of the birds are improved due to supplementation with insect meals, significant changes in microbiota populations were marked. The predominant taxa of the GIT of broiler chickens belong to the phylum Firmicutes and consist of mainly cellulolytic and amylolitic Clostridia followed by Bacillus spp., Lactobacillus spp. and Enterococcus spp. (Egorova et al., 2016). In the current study, in the ileal digesta, counts of the Clostridium coccoides-Eubacterium rectale cluster were the highest in insect supplemented treatments in comparison with NC. Moreover, Lactobacillus spp./Enterococcus spp. counts increased with supplementation of T. molitor meal. Shelfordella lateralis supplementation increased the Clostridium leptum subgroup and Clostridium coc-
coides-Eubacterium rectale cluster counts in the crop, while $H$. illucens $(0.2 \%)$ addition increased Bacteroides-Prevotella, the Clostridium coccoidesEubacterium rectale cluster and Streptococcus spp./ Lactococcus spp. in the caeca.

The Clostridium leptum subgroup includes many species that are members of the genera Clostridium, Eubacterium and Ruminococcus, which are mostly butyrate producing and fibrolytic species that have significant effects on gut health (Lay et al., 2005). Species of this genus produce organic acids, including butyrate, acetate, lactate or formate, but not propionic and succinic acids, as primary products of dietary fibre fermentation. Therefore, similar to the Clostridium leptum subgroup, the abundance of $E$. rectale is a good indicator of the butyrate-producing microbiota, which indirectly affect epithelial cell structure and function, particularly in the lower regions of the GIT. Observed changes in the Clostridium leptum subgroup, Clostridium coccoides-Eubacterium rectale, and Bacteroides-Prevotella show that the relatively low inclusion of the insect meals, particularly $S$. lateralis and H. illucens, can affect the GIT microbiome. Moreover, supplementation of $S$. lateralis resulted in improvement of BWG of the chickens, and this could be connected to the higher frequency of the Clostridium leptum subgroup, as well as Clostridium coccoides-Eubacterium rectale. Finally, the addition of insect full-fat meals also reduced the $\mathrm{pH}$ value in the crop, particularly with the supplementation of 0.1 or $0.2 \%$ of G. assimilis, $0.1 \%$ of G. sigillatus or $0.2 \%$ of $S$. lateralis. However, even in lower regions of the GIT (caeca), supplementation with $0.2 \%$ of $S$. lateralis decreased the $\mathrm{pH}$ value. This acidification effect can also reflect the potential bacteriostatic role of insect meals in the GIT of poultry, while fermentation processes contribute to the formation of short-chain fatty acids and shifts in $\mathrm{pH}$ values.

It is well-documented that insects produce AMPs that have broad-spectrum activity against both Gram-positive and Gram-negative bacteria, including Staphylococcus aureus (MRSA), Klebsiella pneumoniae, Shigella sonnei, Pseudomonas aeruginosa and Escherichia coli, and fungi, viruses and parasites (Park et al., 2014; Yi et al., 2014; Józefiak and Engberg, 2017). Additionally, the chitin content in insect meals could activate the innate immune system because of the fungistatic and immunoadjuvant properties (Dutta et al., 2004). The results of the present study demonstrate that even low supplementation of the full-fat insect to broiler chicken 
diets can have a statistically significant impact on selected GIT microbiota populations. Therefore in our opinion, the role of AMPs and/or chitin need more research to clarify their potential effects on broiler chicken gut health.

\section{Conclusions}

It can be concluded that supplementation with full-fat insect meals in relatively small amounts, i.e. from 0.05 to $0.2 \%$, in the diet of broiler chickens can modulate microbiota populations in the gastrointestinal tract of broiler chickens.

\section{Acknowledgments}

This work was supported by several sources, i.e. the funds of Poznań University of Life Sciences; TEAM TECH/2016-2/11-0026 project entitled: Insects as novel protein sources for fish and poultry, financed by Foundation of Polish Science (POIR 4.4); as well as founds of the National Centre for Research and Development, no POIR.01.01.01-00-0828/15, entitled: InnSecta: innovative technology of feedstuffs production based on insect biomass; and following grant: Brigde Alpha, HiProMine S.A - The National Centre for Research and Development (Poland).

\section{References}

Awoniyi T.A.M., Aletor V.A., Aina J.M., 2003. Performance of broiler chickens fed on maggot meal in place of fishmeal. Int. J. Poult. Sci. 2, 271-274, https://doi.org/10.3923/ijps.2003.271.274

Bovera F., Piccolo G., Gasco L., Marono S., Loponte R., Vassalotti G., Mastellone V., Lombardi P., Attia Y.A., Nizza A., 2015. Yellow mealworm larvae (Tenebrio molitor, L.) as a possible alternative to soybean meal in broiler diets. Br. Poult. Sci. 56, 569575, https://doi.org/10.1080/00071668.2015.1080815

Choi S.C., Ingale S.L., Kim J.S., Park Y.K., Kwon I.K., Chae B.J., 2013a. Effects of dietary supplementation with an antimicrobial peptide-P5 on growth performance, nutrient retention, excreta and intestinal microflora and intestinal morphology of broilers. Anim. Feed Sci. Technol. 185, 78-84, https://doi. org/10.1016/j.anifeedsci.2013.07.005

Choi S.C., Ingale S.L., Kim J.S., Park Y.K., Kwon I.K., Chae B.J., 2013b. An antimicrobial peptide-A3: effects on growth performance, nutrient retention, intestinal and faecal microflora and intestinal morphology of broilers. Br. Poult. Sci. 54, 738-746, https://doi.org/10.1080/00071668.2013.838746

Dunislawska A., Slawinska A., Stadnicka K., Bednarczyk M., Gulewicz P., Jozefiak D., Siwek M., 2017. Synbiotics for broiler chickens - in vitro design and evaluation of the influence on host and selected microbiota populations following in ovo delivery. PLoS ONE 12, e0168587, https://doi.org/10.1371/ journal.pone. 0168587

Dutta P.K., Dutta J., Tripathi V.S., 2004. Chitin and chitosan: chemistry, properties and applications. J. Sci. Ind. Res. 63, 20-31
Egorova T.A., Lenkova T.N., Il'ina L.A. et al., 2016. The Saccharomyces sp. and Bacillus subtilis based probiotics influence on chicken broiler productivity and caecum microbiome community. Agric. Biol. 51, 891-902, https://doi.org/10.15389/ agrobiology.2016.6.891eng

Hwangbo J., Hong E.C., Jang A., Kang H.K., Oh J.S., Kim B.W., Park B.S., 2009. Utilization of house fly-maggots, a feed supplement in the production of broiler chickens. J. Environ. Biol. 30, 609-614

Józefiak A., Engberg R.M., 2017. Insect proteins as a potential source of antimicrobial peptides in livestock production. A review. J. Anim. Feed Sci. 26, 87-99, https://doi.org/10.22358/ jafs/69998/2017

Józefiak D., Józefiak A., Kierończyk B., Rawski M., Świątkiewicz S., Długosz J., Engberg R.M., 2016. Insects - a natural nutrient source for poultry - a review. Ann. Anim. Sci. 16, 297-313, https://doi.org/10.1515/aoas-2016-0010

Józefiak D., Kierończyk B., Juśkiewicz J., Zduńczyk Z., Rawski M., Długosz J., Sip A., Højberg O., 2013. Dietary nisin modulates the gastrointestinal microbial ecology and enhances growth performance of the broiler chickens. PLoS ONE 8, e85347, https://doi.org/10.1371/journal.pone.0085347

Józefiak D., Sip A., Rawski M., Rutkowski A., Kaczmarek S., Hojberg O., Jensen B.B., Engberg R.M., 2011. Dietary divercin modifies gastrointestinal microbiota and improves growth performance in broiler chickens. Br. Poult. Sci. 52, 492-499, https://doi.org/10.1080/00071668.2011.602963

Józefiak D., Sip A., Rutkowski A., Rawski M., Kaczmarek S., WołuńCholewa M., Engberg R.M., Højberg O., 2012. Lyophilized Carnobacterium divergens AS7 bacteriocin preparation improves performance of broiler chickens challenged with Clostridium perfringens. Poult. Sci. 91, 1899-1907, https://doi. org/10.3382/ps.2012-02151

Józefiak D., Świątkiewicz S., Kierończyk B., Rawski M., Długosz J., Engberg R.M., Højberg O., 2016. Clostridium perfringens challenge and dietary fat type modifies performance, microbiota composition and histomorphology of the broiler chicken gastrointestinal tract. Eur. Poult. Sci. 80, https://doi. org/10.1399/eps.2016.130

Kierończyk B., Pruszyńska-Oszmałek E., Świątkiewicz S., Rawski M., Długosz J., Engberg R.M., Józefiak D., 2016. The nisin improves broiler chicken growth performance and interacts with salinomycin in terms of gastrointestinal tract microbiota composition. J. Anim. Feed Sci. 25, 309-316, https://doi. org/10.22358/jafs/67802/2016

Lay C., Sutren M., Rochet V., Saunier K., Doré J., Rigottier-Gois L., 2005. Design and validation of $16 \mathrm{~S}$ rRNA probes to enumerate members of the Clostridium leptum subgroup in human faecal microbiota. Environ. Microbiol. 7, 933-946, https://doi. org/10.1111/j.1462-2920.2005.00763.x

Loughrey A.G., 1951. A food-habit study of juvenile ring-necked pheasants on Pelee Island, Ontario. MSc Thesis. The University of Western Ontario. London, Ontario (Canada)

Makkar H.P.S., Tran G., Heuzé V., Ankers P., 2014. State-of-the-art on use of insects as animal feed. Anim. Feed Sci. Technol. 197, 1-33, https://doi.org/10.1016/j.anifeedsci.2014.07.008

Maurer V., Holinger M., Amsler Z., Früh B., Wohlfahrt J., Stamer A., Leiber F., 2015. Replacement of soybean cake by Hermetia illucens meal in diets for layers. J. Insects Food Feed 2, 83-90, https://doi.org/10.3920/JIFF2015.0071

Pan D., Yu Z., 2014. Intestinal microbiome of poultry and its interaction with host and diet. Gut Microbes 5, 108-119, https://doi. org/10.4161/gmic. 26945 
Park S.-I., Chang B.S., Yoe S.M., 2014. Detection of antimicrobial substances from larvae of the black soldier fly, Hermetia illucens (Diptera: Stratiomyidae). Entomol. Res. 44, 58-64, https://doi. org/10.1111/1748-5967.12050

Pretorius Q., 2011. The evaluation of larvae of Musca domestica (common house fly) as protein source for broiler production. MSc Thesis. Stellenbosch University. Stellenbosch (South Africa)

Ptak A., Bedford M.R., Świątkiewicz S., Żyła K., Józefiak D., 2015. Phytase modulates ileal microbiota and enhance growth performance of the broiler chickens. PLOS ONE 10, e0119770, https://doi.org/10.1371/journal.pone.0119770

Rumble M.A., Anderson S.H., 1996. Feeding ecology of Merriam's turkeys (Meleagris gallopavo merriami) in the Black Hills, South Dakota. Am. Midl. Nat. 136, 157-171, https://doi. org $/ 10.2307 / 2426641$

Salanitro J.P., Blake I.G., Muirehead P.A., Maglio M., Goodman J.R., 1978. Bacteria isolated from the duodenum, ileum, and cecum of young chicks. Appl. Environ. Microbiol. 35, 782-790

Stanley D., Hughes R.J., Moore R.J., 2014. Microbiota of the chicken gastrointestinal tract: influence on health, productivity and disease. Appl. Microbiol. Biotechnol. 98, 4301-4310, https://doi. org/10.1007/s00253-014-5646-2
Wang D., Zhai S.W., Zhang C.X., Bai Y.Y., An S.H., Xu Y.N., 2005. Evaluation on nutritional value of field crickets as a poultry feedstuff. Asian-Australas. J. Anim. Sci. 18, 667-670, https:// doi.org/10.5713/ajas.2005.667

Wen L.-F., He J.-G., 2012. Dose-response effects of an antimicrobial peptide, a cecropin hybrid, on growth performance, nutrient utilisation, bacterial counts in the digesta and intestinal morphology in broilers. Br. J. Nutr. 108, 1756-1763, https://doi. org/10.1017/S0007114511007240

Xiao H., Shao F., Wu M., Ren W., Xiong X., Tan B., Yin Y., 2015. The application of antimicrobial peptides as growth and health promoters for swine. J. Anim. Sci. Biotechnol. 6, 19, https:// doi.org/10.1186/s40104-015-0018-z

Yi H.-Y., Chowdhury M., Huang Y.-D., Yu X.-Q., 2014. Insect antimicrobial peptides and their applications. Appl. Microbiol. Biotechnol. 98, 5807-5822, https://doi.org/10.1007/s00253-014$5792-6$ 